\title{
Dampak Kebijakan BI Rate Repo 7 Days terhadap Kinerja Bank Pemerintah
}

\author{
Sofyan Marwansyah ${ }^{1}$, Sri Rusiyati ${ }^{2}$ \\ ${ }^{1}$ Universitas Bina Sarana Informatika, sofyan.smw@bsi.ac.id \\ ${ }^{2}$ Sekolah Tinggi Manajemen Informatika dan Komputer Nusa Mandiri Jakarta, \\ sri.siq@nusamandiri.ac.id
}

\begin{abstract}
ABSTRAK
Kebijakan untuk mengatasi jalur inflasi biasanya bank sentral menggunakan kebijakan suku bunga yang disebut BI Rate, tetapi kebijakan BI Rate dianggap tidak efektif bagi bank karena memerlukan waktu yang lama hingga satu tahun, sehingga bank sentral menerbitkan 7- day Repo BI Rate dengan tujuan efektif dalam menjalankan kebijakan sistem keuangan. Tujuan penulisan ini adalah pertama; untuk mengetahui pengaruh kebijakan Repo BI Rate terhadap Rasio Modal dan Rasio Profitabilitas bank Pemerintah, kedua; untuk melihat apakah ada perbedaan yang signifikan dalam kinerja modal dan profitabilitas bank pemerintah karena kebijakan repo 7 hari BI Rate. Hasil penelitian diperoleh bahwa BI Rate memiliki hubungan negatif signifikan sedangkan rasio profitabilitas (ROE) memiliki hubungan signifikan positif; BI Rate mempengaruhi Rasio Modal (CAR) 27,6\% sedangkan Rasio Profitabilitas 17,2\%; Tingkat Rasio Modal (CAR) memiliki perbedaan yang signifikan antara sebelum kebijakan Repo BI Rate dan setelah kebijakan yang meningkat dari 18,65 menjadi 20,42; Rasio profitabilitas (ROE) memiliki perbedaan yang signifikan antara sebelum kebijakan Repo BI Rate dan setelah kebijakan, yang menurun dari 20,24 menjadi 16,59.
\end{abstract}

Kata Kunci : BI Rate, Rasio Permodalan, Rasio Profitabilitas

\begin{abstract}
The policy to overcome the inflation lane is usually the central bank uses an interest rate policy called the BI Rate, but the BI Rate policy is deemed ineffective for banks because it requires a long time to a year, so the central bank issues a 7-day BI Rate Repo with the aim to effective in carrying out financial system policies. The purpose of this writing is first; to determine the influence of BI Rate Repo policy on Capital Ratios and Profitability ratios of Government banks, second; to see if there are significant differences in capital performance and profitability of government banks due to the 7 Days BI Rate repo policy. The research results obtained that the BI Rate has a negative significant relationship to the capital ratio (CAR) while the profitability ratio (ROE) has a positive significant relationship; The BI Rate affects the Capital Ratio (CAR) of 27.6\% while the Profitability Ratio is 17.2\%; The Capital Ratio Rate (CAR) has a significant difference between before the BI Rate Repo policy and after the policy which has increased from 18.65 to 20.42; The profitability ratio (ROE) has a significant difference between before the BI Rate Repo policy and after the policy, which decreased from 20.24 to 16.59 .
\end{abstract}

Keywords: BI Rate, Capital Ratio, Profitability Ratio

Naskah diterima:23 Agustus 2019, direvisi: 30 Agustus 2019, diterbitkan: 16 September 2019

\section{PENDAHULUAN}

Suatu Perekonomian negara akan terlihat stabil bila roda pembangunan khususnya dunia perbankan berjalan dengan baik, salah satu tugas Bank Indonesia sebagai bank central memiliki dua peran yakni sebagai otoritas moneter, dan menjaga stabilitas sistem keuangan dari perbankan. Salah satu peran dalam menjaga stabilitas sistem keuanganan adalah kebijakan mengenai 
tingkat suku bunga. Suku bunga yang digunakan oleh Bank Indonesia pada saat ini adalah BI Rate, namun kebijakan BI Rate yang harus menunggu waktu yang lama bagi perbankan untuk mengikuti kebijakan tersebut membuat kebijakan perbankan kurang efektif dalam mengatasi inflasi. Dikarenakan permasalahan yang dihadapi begitu komplek tersebut maka pada pertengahan april $2016 \mathrm{BI}$ mengeluarkan kebijakan baru mengenai suku bunga yakni BI Rate Repo 7 Days untuk meningkatkan efektifitas kebijakan otoritas moneter.

Pergerakan BI 7-Days Reverse Repo Rate (BI7DRRR) sepanjang tahun 2018 melalui kebijakan BI menunjukkan kecenderungan mengalami kenaikan seperti acuan Bunga pertama kali terjadi kenaikan pada tanggal 18 Mei 2018 sebesar 25 bps (4.5\%), namun hal tersebut masih tidak cukup untuk mengembalikan nilai tukar rupiah cenderung yang melemah sehingga pada tanggal 29 Mei 2018 naik 25 bps (4.75\%), tanggal 29 Juni 2018 mengalami kenaikan 50 bps (5.25\%), 15 Agustus naik 25 bps (5.5\%), 27 September 2018 naik 25 bps $(5.75 \%)$ dan 15 Nopember 2018 naik 25 bps $(6.00 \%)$ (http.//www.bi.go.id). Hal tersebut dapat berdampak pada kinerja perbankan pada umunya.

Berdasarkan permasalah tersebut di atas maka penulis ingin meneliti apakah kebijakan dikeluarkannya BI Rate Repo tersebut berdampak signifikan terhadap kinerja bank pemerintah khususnya dalam rasio permodalan dan rasio profitabilitas.

\section{KAJIAN LITERATUR}

\section{BI Rate}

"BI Rate adalah kebijakan tingkat suku bunga yang menerminkan suatu sikap atau stance kebijakan moneter yang penetapannya dilakukan oleh Bank Indonesia dan diumumkan kepada masyarakat umum atau publik" (http.//www.bi.go.id)

Menurut (Indonesia, n.d.) dalam inflation targeting framework menyatakan "BI Rate adalah tingkat suku bunga yang merupakan instrumen sinyaling dari Bank Indonesia ditetapkan melalui RDG (Rapat Dewan Gubernur) setiap triwulanan dan berlaku selama triwulan berjalan (satu triwulan), kecuali jika RDG bulanan menetapkan berbeda dalam triwulan yang sama" (http.//www.bi.go.id).

Dampak yang ingin diharapkan dengan diterapkannya BI 7 days menurut (Indonesia, n.d.) Pertama, dapat menguatnya sinyal pada kebijakan moneter dengan tingkat suku bunga (Reverse) Repo Rate 7 hari sebagai acuan utama di pasar keuangan. Kedua, meningkatnya efektivitas transmisi pada kebijakan moneter melalui pengaruhnya pada pergerakan suku bunga pasar uang dan suku bunga perbankan. Ketiga, akan terbentuk pasar keuangan yang lebih dalam, khususnya transaksi dan pembentukan struktur tingkat suku bunga di Pasar Uang Antar Bank (PUAB) untuk tenor 3-12 bulan (http.//www.bi.go.id).

\section{Rasio Permodalan}

Berikut ini adalah salah satu cara untuk mengukur jumlah kapital yang ada pada suatu bank telah memadai atau belum, (KJPP Tri, Santi \& Rekan, 2011):

Primary Ratio. Rasio ini dapat digunakan untuk mengukur kemampuan permodalan bank dalam menyanggah aset akibat berbagai kerugian yang tidak dapat dihindari. semakin besar semakin bagus

Primary Ratio $=$ Equity/Total Assets

Capital Ratio. Rasio ini dapat digunakan untuk mengukur kemampuan permodalan bank dalam menyanggah sejumlah pinjaman pada nasabah. semakin besar semakin bagus

Capital Ratio = Equity/Total Loans

Deposit Risk Ratio. Rasio ini dapat digunakan untuk mengukur kemampuan bank untuk membayar kembali dana yang disimpan para deposannya, yang harus dijamin pembayarannya oleh capital bank. semakin besar semakin bagus

Deposit Risk Ratio = Equity/Total Deposit Capital Adequacy Ratio (CAR). Rasio ini dapat digunakan untuk mengukur kecukupan modal bank guna menutupi kemungkinan kerugian dalam pemberian kredit dan perdagangan surat-surat berharga. semakin besar semakin bagus

Capital Adequacy Ratio = Equity Capital/ATMR (Aktiva Tertimbang Menurut Risiko) 
3. Rasio Profitabilitas

"Rasio Profitabilitas adalah kemampuan menghasilkan laba selama periode tertentu dengan menggunakan aktiva atau modal, baik modal secara keseluruhan maupun modal sendiri" hal ini sama seperti dikutip oleh (Barus \& Leliani, n.d.) dan (Afriyanti, 2011) Sedangkan menurut (Brigham \& Houston, 2013) "profitabilitas juga menunjukkan pengaruh gabungan dari likuiditas, pengelolaan aktiva, dan pengelolaan hutang terhadap hasil-hasil operasi."

(Iskandar, 2008) menyatakan bahwa "Profitabilitas yaitu pencapaian hasil akhir yang dieroleh oleh manajemen dari setiap kebijakan dan keputusan, Rasio Profitabilitas akan digunakan untuk mengukur suatu kemampuan perusahaan dalam menjalankan usahanya untuk memperoleh keuntungan dengan memanfaatkan aktiva atau asset yang dimiliki dan rasio profitabilitas terdiri dari ROA (Return on Aset), ROE (Return On Equity) dan Profit Margin"

\section{Profitabilitas Bank}

Profitabilitas sangat penting bagi perusahaan dan investor, keuntungan yang lebih tinggi yang dapat dicapai oleh perusahaan, akan membuat perusahaan lebih menarik di mata investor. Sedangkan untuk investor, terutama pemegang saham, digunakan untuk menilai dalam mengambil keputusan berinvestasi di perusahaan tersebut (Alamzah \& Sanusi, 2015).

Menurut (Tailab, 2014) ada beberapa pengukuran performa keuangan seperti Return on Assets (ROA) cara perhitungannya dengan membandingkan laba bersih dengan total aset, Return on Investment (ROI) dengan cara membandingkan laba bersih dengan modal, Return on Equity (ROE), dan Operati dengan cara membandingkan laba bersih dengan total ekuitas on Profit Margin (OPM) dengan cara membandingkan Laba Bersih Sebelum Pajak dan Bunga / Penjualan Bersih.

Menurut (Missy, Yuanita, Budiyanto, \& Riyadi, 2016) profitabilitas diukur dengan Return on Assets (ROA), Return on Equity (ROE) dan laba per saham atau Earning Per Share (EPS) yang perhitungannya dengan cara mambandingkan laba bersih dengan jumlah saham. Alasan untuk menggunakan EPS adalah karena dapat menerangkan prospek pendapatan perusahaan di masa depan.

Menurut (Riyadi, 2016), untuk memperoleh hasil perhitungan rasio supaya agar mendekati pada kondisi yang sesungguhnya, maka posisi asset atau modal dilakukan perhitungan secara rata-rata selama periode perhitungan.

\section{Tujuan Rasio Profitabilitas}

Menurut (Kasmir, 2012) menyatakan bahwa: rasio profitabilitas mempunyai tujuan bagi perusahaan, maupun bagi pihak luar perusahaan, yaitu: (1) Untuk menghitung atau mengukur laba yang diperoleh suatu perusahaan dalam satu periode tertentu. (2) Untuk menilai posisi laba suatu perusahaan pada tahun sebelumnya dengan tahun berjalan. (3) Untuk menilai perkembangan tingkat laba dari masa ke masa. (4) Untuk menilai besarnya perolehan laba bersih sesudah pajak dengan modal sendiri. (5) Untuk mengukur produtivitas seluruh dana suatu perusahaan yang dimanfaatkan baik berasal dari modal pinjaman maupun modal sendiri.

\section{Manfaat Rasio Profitabilitas}

Menurut (Kasmir, 2012) "Manfaat rasio profitabilitas adalah: (1) Mengetahui besarnya tingkat laba yang diperoleh perusahaan dalam satu periode. (2) Mengetahui posisi laba perusahaan tahun sebelumnya dengan tahun sekarang. (3) Mengetahui perkembangan laba dari waktu ke waktu. (4) Mengetahui besarnya laba bersih sesudah pajak dengan modal sendiri. (5) Mengetahui besarnya produktivitas dari seluruh dana perusahaan yang digunakan baik modal pinjaman maupun modal sendiri”.

\section{METODE PENELITIAN}

Pada penelitian ini penulis menggunakan teknik pengumpulan data studi pustaka dan dokumentasi dengan jenis data sekunder yang diambil dari website masing-masing bank dan data BI Rate periode 2015 hingga 2017 yang 
diperoleh dari website resmi BI. Teknik pengambilan sampel menggunakan purposive sampling dimana populasinya adalah seluruh bank pemerintah yang terdaftar di Bursa Efek Indonesia dan sampel yang digunakan bnak pemerintah dengan laporan keuangan periode 2015 sampai dengan 2017. Teknik analisis data yang digunakan adalah analisis regresi linear sederhana antara variabel BI Rate terhadap Rasio Permodalan (CAR) dan Rasio Profitabilitas (ROE) dan melakukan analisis Perbandingan Rasio Profitabilitas (ROE) dan Rasio Permodalan (CAR) bank BUMN sebelum dan sesudah penerapan BI Rate
Repo. Data menggunakan rasio permodalan (CAR), Rasio Profitabilitas (ROE), per triwulan periode 2015 hingga tahun 2017. Metode dalam penelitian ini menggunakan uji Koefisien korelasi, Uji koefisien determinasi dan uji paired sample $\mathrm{T}$ test dengan bantuan software SPSS V.21

\section{PEMBAHASAN}

Berdasarkan Hasil pengamatan mengenai Nilai BI Rate periode 2015 hingga 2017 per triwulan melalui web BI dapat dilihat pada tabel berikut

Tabel III.1

Data Perkembangan BI Rate periode 2015 s.d 2017

\begin{tabular}{|c|c|c|c|c|c|c|c|c|c|c|c|c|}
\hline Thn & & & & & & & 2016 & & & & & \\
\hline \multirow{2}{*}{ BI Rate } & I & II & III & IV & I & II & III & IV & I & II & III & IV \\
\hline & 7.5 & 7.5 & 7.5 & 7.5 & 7 & 5.87 & 5.17 & 4.75 & 4.75 & 4.75 & 4.5 & 4.25 \\
\hline
\end{tabular}

Berdasarkan hasil penelitian diketahui bahwa besarnya nilai BI rate berikisar $7 \%$ di tahun
2015 dan pada awal tahun 2016 dan tahun 2017 BI Rate berkisar 4\% hingga 5\%.

Gambar III.1

Perkembangan BI Rate

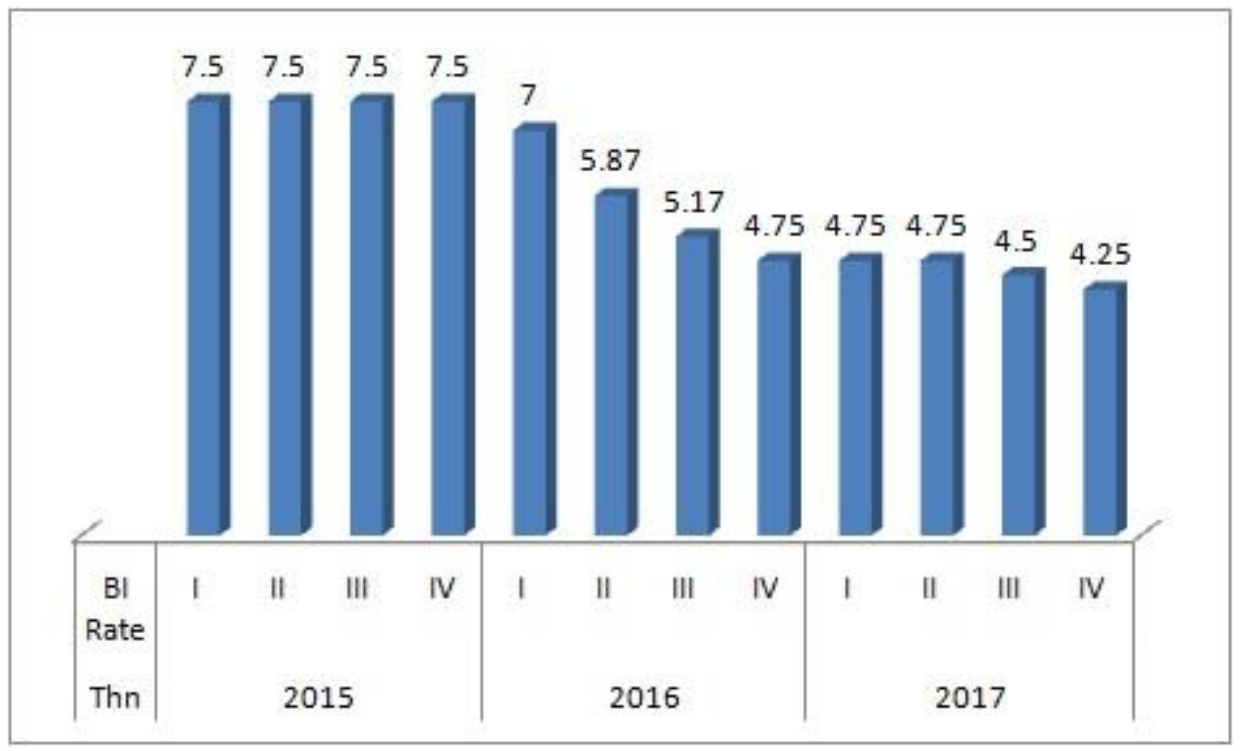

Berdasarkan gambar grafik di atas dapat mengalami penurunan sejak menggunakan BI disimpulkan nilai BI Rate selam tiga tahun Rate Repo 7 days.

Tabel III.2 
Data CAR Bank BUMN

\begin{tabular}{|c|c|c|c|c|c|c|c|}
\hline \multicolumn{8}{|c|}{ CAR } \\
\hline \multirow{2}{*}{ Jenis Bank } & \multicolumn{2}{|l|}{ Tahun } & \multicolumn{2}{|c|}{2015} & \multirow[b]{2}{*}{ IV } & \multicolumn{2}{|c|}{2016} \\
\hline & Kwartal & I & II & III & & I & II \\
\hline $\mathrm{BNI}$ & & 17.83 & 17.11 & 17.43 & 19.49 & 19.87 & 19.3 \\
\hline BTN & & 15.05 & 14.78 & 15.78 & 16.97 & 16.5 & 22.07 \\
\hline BRI & & 20.08 & 20.41 & 20.59 & 20.59 & 19.49 & 22.1 \\
\hline MANDIRI & & 17.87 & 17.63 & 17.81 & 18.6 & 18.48 & 21.78 \\
\hline Average & & 17.71 & 17.48 & 17.90 & 18.91 & 18.59 & 21.31 \\
\hline \multirow{2}{*}{ Jenis Bank } & Tahun & \multicolumn{2}{|c|}{2016} & \multicolumn{4}{|c|}{2017} \\
\hline & Kwartal & III & IV & I & II & III & IV \\
\hline $\mathrm{BNI}$ & & 18.39 & 19.36 & 19 & 18.99 & 19.01 & 18.53 \\
\hline BTN & & 20.6 & 20.34 & 18.9 & 18.38 & 16.97 & 18.87 \\
\hline BRI & & 21.88 & 22.91 & 20.86 & 21.67 & 22.17 & 22.96 \\
\hline MANDIRI & & 22.63 & 21.36 & 21.11 & 21.55 & 21.98 & 21.64 \\
\hline Average & & 20.88 & 20.99 & 19.97 & 20.15 & 20.03 & 20.50 \\
\hline
\end{tabular}

Berdasarkan data rasio Permodalan (CAR) di atas dapat disimpulkan bahwa; pertama; bank bni pada kwartal I tahun 2015 berkisar $17.83 \%$ dan mengalami kenaikan berturutturut hingga kuwartal III tahun 2017 namun kembali menurun pada kuwartal IV tahun 2017 menjadi 18.53\%, kedua; bank BTN mengalami fluktuasi nilai CAR per kwartal terendah berkisar $14.78 \%$ pada kuwartal II tahun 2015 dan tertinggi pada kwartal III tahun 2016 berkisar 20.6\%, ketiga; Bank BRI nilai CAR terus mengalami penurunan dari kwartal I tahun 2015 berkisar $20.08 \%$ menjadi $19.49 \%$ di kwartal I tahun 2016 dan mengalami kenaikan kembali pada tahun 2017, keempat; bank mandiri nilai rasio CAR mengalami fluktuatif dari tahun 2015 hingga 2017 dimana nilainya hanya berkisar $17 \%$ hingga $22 \%$.

Tabel III.3

Data ROE Bank BUMN

\begin{tabular}{l|l|l|l|l|l|l|l|}
\hline \multicolumn{9}{c}{ ROE } \\
\hline \multirow{3}{*}{ Jenis Bank } & Tahun & \multicolumn{9}{|c|}{2015} & \multicolumn{2}{|c}{2016} \\
\cline { 2 - 9 } & Kwartal & I & II & III & IV & I & II \\
\hline
\end{tabular}


Jurnal Ecodemica, Vol. 3 No. 2 September 2019

\begin{tabular}{|c|c|c|c|c|c|c|c|}
\hline \multicolumn{2}{|l|}{ BNI } & 23.08 & 9.54 & 16.06 & 17.21 & 17.89 & 12.59 \\
\hline \multicolumn{2}{|l|}{ BTN } & 15.31 & 15.62 & 15.13 & 16.84 & 15.89 & 16.22 \\
\hline \multicolumn{2}{|l|}{ BRI } & 29.84 & 29.22 & 29.6 & 29.89 & 26.55 & 25.24 \\
\hline \multicolumn{2}{|l|}{ MANDIRI } & 23.84 & 23.68 & 22.49 & 23.03 & 17.84 & 13.33 \\
\hline \multicolumn{2}{|l|}{ Average } & 23.02 & 19.52 & 20.82 & 21.74 & 19.54 & 16.85 \\
\hline \multirow{2}{*}{ Jenis Bank } & Tahun & \multicolumn{2}{|c|}{2016} & \multicolumn{4}{|c|}{2017} \\
\hline & Kwartal & III & IV & I & II & III & IV \\
\hline \multicolumn{2}{|l|}{$\mathrm{BNI}$} & 14.61 & 15.54 & 16.03 & 15.56 & 15.94 & 15.6 \\
\hline \multicolumn{2}{|l|}{ BTN } & 15.76 & 18.35 & 14.6 & 15.64 & 16.34 & 18.11 \\
\hline \multicolumn{2}{|l|}{ BRI } & 23.97 & 23.08 & 18.77 & 19.12 & 19.27 & 20.03 \\
\hline \multicolumn{2}{|l|}{ MANDIRI } & 13.76 & 11.12 & 13.4 & 14.43 & 14.68 & 14.53 \\
\hline \multicolumn{2}{|l|}{ Average } & 17.03 & 17.02 & 15.70 & 16.19 & 16.56 & 17.07 \\
\hline
\end{tabular}

Berdasarkan data rasio Profitabilitas (ROE) di atas dapat disimpulkan bahwa; pertama; bank bni memiliki nilai ROE yang stabil antara $14 \%$ hingga $23 \%$ meski sempat mengalami penurunan drastis yakni berkisar $9.5 \%$ di kwartal II tahun 2015, kedua; bank BTN mengalami fluktuasi nilai ROE per kwartal terendah berkisar $14.6 \%$ pada kuwartal III tahun 2015 dan tertinggi pada kwartal IV tahun 2016 berkisar 18.35\%, ketiga; Bank BRI nilai ROE terendah berkisar 18.77 berada di kwartal I tahun 2017 dan tertinggi berkisar $29.89 \%$ berada di kwartal IV tahun 2016, keempat; bank mandiri nilai ROE terendah berkisar 11.12 berada di kwartal IV tahun 2016 dan tertinggi berkisar $23.84 \%$ berada di kwartal I tahun 2015.

1. UJI Koefisien Determinasi

a. Pengaruh BI Rate Terhadap Rasio Permodalan (CAR)

H01: Tidak Ada Pengaruh yang signifikan antara BI Rate terhadap Rasio Permodalan (CAR)

Ha1: Ada Pengaruh yang signifikan antara BI Rate Terhadap Rasio Permodalan (CAR)

Tabel III.4

Model Summary

\begin{tabular}{|c|c|c|c|c|c|c|c|c|c|}
\hline \multicolumn{10}{|c|}{ Model Summary } \\
\hline \multirow[b]{2}{*}{ Model } & \multirow[b]{2}{*}{$\mathrm{R}$} & \multirow[b]{2}{*}{ R Square } & \multirow[b]{2}{*}{$\begin{array}{l}\text { Adjusted } \\
\text { R Square }\end{array}$} & \multirow[b]{2}{*}{$\begin{array}{l}\text { Std. Error of } \\
\text { the Estimate }\end{array}$} & \multicolumn{5}{|c|}{ Change Statistics } \\
\hline & & & & & $\begin{array}{l}\mathrm{R} \\
\text { Square } \\
\text { Change }\end{array}$ & $\begin{array}{l}\mathrm{F} \\
\text { Change }\end{array}$ & $\begin{array}{l}\mathrm{df} \\
1\end{array}$ & $\begin{array}{l}\mathrm{df} \\
2\end{array}$ & $\begin{array}{l}\text { Sig. F } \\
\text { Change }\end{array}$ \\
\hline 1 & .526 & .276 & .261 & 1.79228 & .276 & 17.566 & 1 & 46 & .000 \\
\hline
\end{tabular}

a. Predictors: (Constant), BI RATE

Berdasarkan hasil di atas diperoleh Bahwa nilai Sig. Sebesar $0.000<0.05$ maka keputusan terima Ha, kesimpulannya ada pengaruh antara BI Rate terhadap rasio 
Permodalan (CAR). Apabila di lihat dari nilai R Squre diperoleh 0.276 atau $27.6 \%$, dimana bahwa rasio permodalan dipengaruhi oleh BI Rate sebesar $27.6 \%$, sisanya $72.4 \%$ dipengaruh faktor lain

b. Pengaruh BI Rate Terhadap Rasio Profitabilitas (ROE)
Hipotesa:

H01: Tidak Ada Pengaruh yang signifikan antara BI Rate terhadap Rasio Profitabilitas (ROE)

Ha1: Ada Pengaruh yang signifikan antara BI Rate Terhadap Rasio Profitabilitas (ROE)

Tabel III.5

Model Summary

\begin{tabular}{|c|c|c|c|c|c|c|c|c|c|}
\hline \multicolumn{10}{|c|}{ Model Summary } \\
\hline \multirow[b]{2}{*}{ Model } & \multirow[b]{2}{*}{$\mathrm{R}$} & \multirow[b]{2}{*}{ R Square } & \multirow[b]{2}{*}{$\begin{array}{l}\text { Adjusted } \\
\text { R Square }\end{array}$} & \multirow{2}{*}{$\begin{array}{l}\text { Std. } \\
\text { Error of } \\
\text { the } \\
\text { Estimate }\end{array}$} & \multicolumn{5}{|c|}{ Change Statistics } \\
\hline & & & & & $\begin{array}{l}\mathrm{R} \\
\text { Square } \\
\text { Change }\end{array}$ & $\begin{array}{l}\mathrm{F} \\
\text { Change }\end{array}$ & $\begin{array}{l}\mathrm{df} \\
1\end{array}$ & $\begin{array}{l}\mathrm{df} \\
2\end{array}$ & $\begin{array}{l}\text { Sig. F } \\
\text { Change }\end{array}$ \\
\hline 1 & $.414^{\mathrm{a}}$ & .172 & .154 & 4.66294 & .172 & 9.539 & 1 & 46 & .003 \\
\hline
\end{tabular}

Berdasarkan hasil di atas diperoleh Bahwa nilai Sig. Sebesar $0.003<0.05$ maka keputusan terima $\mathrm{Ha}$, kesimpulannya ada pengaruh antara BI Rate terhadap rasio Profitabilitas (ROE). Apabila di lihat dari nilai R Squre diperoleh 0.172 atau $17.2 \%$, dimana bahwa rasio permodalan dipengaruhi oleh BI Rate sebesar $17.2 \%$, sisanya $82.8 \%$ dipengaruh faktor lain

2. UJI Paired Sampel T Test a. UJI Perbandingan Rasio Permodalan

Ho3: Tidak ada perbedaan antara nilai Rasio Permodalan (CAR) Bank BUMN antara sebelum Kebijakan BI Rate Repo dengan Sesudah

Ha3: ada perbedaan antara nilai Rasio Permodalan (CAR) Bank BUMN antara sebelum Kebijakan BI Rate Repo dengan Sesudah

Tabel III.6

Paired Sampel Test Rasio CAR

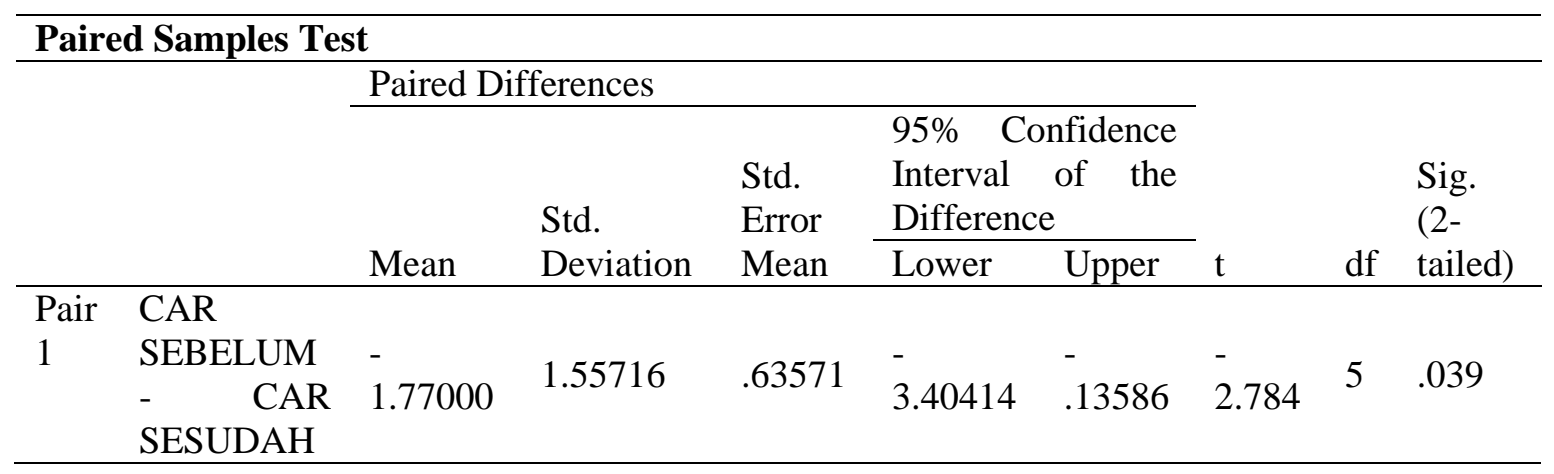

Berdasarkan hasil di atas diperoleh bahwa nilai Sig. Sebesar $0.039<0.05$ maka keputusan terima HA, kesimpulannya ada
Perbedaan Nilai Rasio Permodalan (CAR) sebelum dan sesudah adanya kebijakan BI Rate Repo. 
Tabel III. 7

Paired Sampel Statistik Rasio ROE

\section{Paired Samples Statistics}

\begin{tabular}{llllll}
\hline & & & \multicolumn{2}{l}{$\begin{array}{l}\text { Std. } \\
\text { Mean }\end{array}$} & $\begin{array}{l}\text { Std. Error } \\
\text { Nean }\end{array}$ \\
& & & & \\
\hline Pair 1 & CAR SEBELUM & 18.6500 & 6 & 1.41151 & .57625 \\
& & & & & \\
\cline { 2 - 6 } & CAR SESUDAH & 20.4200 & 6 & .44055 & .17985
\end{tabular}

Berdasarkan hasil Output data di atas diperoleh Nilai rata-rata CAR Bank BUMN Sebelum Kebijakan BI Rate Repo sebesar 19.65 sedangkan sesudah kebijakan BI Rate Repo sebesar 20.42

b. UJI Perbandingan Rasio Profitabilitas

Ho3: Tidak ada perbedaan antara nilai Rasio Profitabilitas (ROE) Bank BUMN antara sebelum Kebijakan BI Rate Repo dengan Sesudah

Ha3: ada perbedaan antara nilai Rasio Profitabilitas (ROE) Bank BUMN antara sebelum Kebijakan BI Rate Repo dengan Sesudah

Tabel III.8

Paired Sampel Test rasio ROE

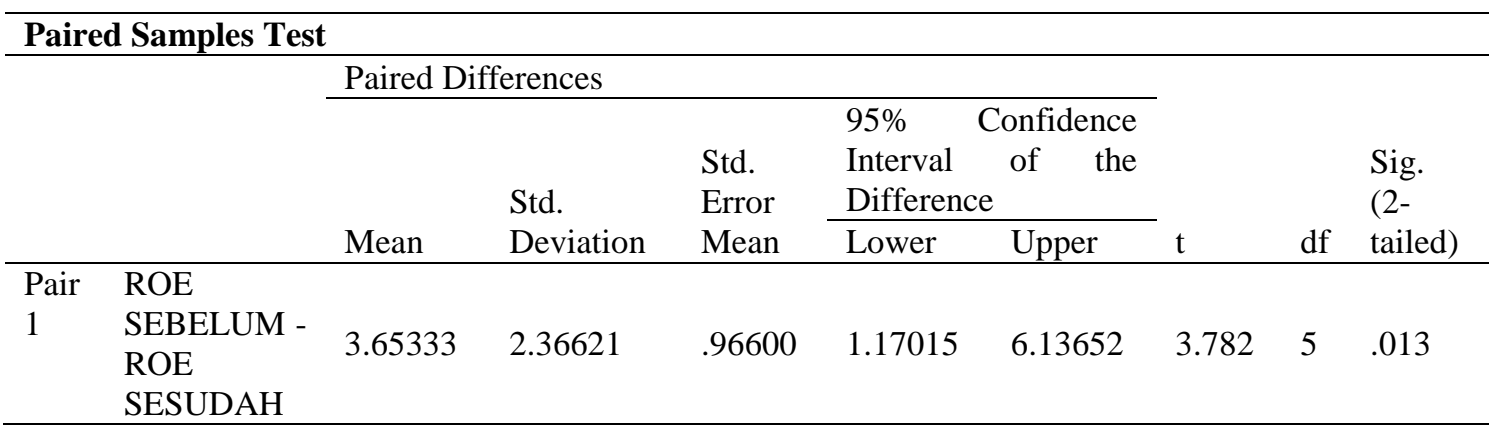

Berdasarkan hasil di atas diperoleh bahwa Perbedaan Nilai Rasio Profitabilitas (ROE) nilai Sig. Sebesar $0.013<0.05$ maka sebelum dan sesudah adanya kebijakan BI keputusan terima HA, kesimpulannya ada Rate Repo.

Tabel III. 9

Paired Sampel Statistik Rasio ROE

\begin{tabular}{|c|c|c|c|c|c|}
\hline \multicolumn{6}{|c|}{ Paired Samples Statistics } \\
\hline & & Mean & $\mathrm{N}$ & $\begin{array}{l}\text { Std. } \\
\text { Deviation }\end{array}$ & $\begin{array}{l}\text { Std. } \\
\text { Error } \\
\text { Mean }\end{array}$ \\
\hline \multirow[t]{2}{*}{ Pair 1} & $\begin{array}{l}\text { ROE } \\
\text { SEBELUM }\end{array}$ & 20.2483 & 6 & 2.13611 & .87206 \\
\hline & $\begin{array}{l}\text { ROE } \\
\text { SESUDAH }\end{array}$ & 16.5950 & 6 & .55888 & .22816 \\
\hline
\end{tabular}

Berdasarkan hasil Output data di atas diperoleh Nilai rata-rata ROE Bank BUMN 
Sebelum Kebijakan BI Rate Repo sebesar 20.24 sedangkan sesudah kebijakan BI Rate

\section{PENUTUP}

Berdasarkan hasil pembahasan uji koefisien korelasi, uji determinasi dan uji perbandingan yang dilakukan antara tingkat BI Rate dengan Rasio permodalan (CAR) dan Rasio Profitabilitas (ROE) adalah sebagai berikut: pertama; BI Rate memiliki hubungan signifikan yang negatif terhadap rasio permodalan (CAR) sedangkan terhadap rasio profitabilitas (ROE) memiliki hubungan signifikan yang positif, kedua; BI Rate mempengaruhi Rasio Permodalan (CAR) sebesar $27.6 \%$ sedangkan terhadap Rasio Profitsbilitas sebesar 17.2\%, ketiga; Tingkat Rasio Permodalan (CAR) memiliki Perbedaan yang signifikan antara sebelum kebijakan BI Rate Repo dengan Sesudah Kebijakan, keempat; Tingkat Rasio profitabilitas (ROE) memiliki Perbedaan yang signifikan antara sebelum kebijakan BI Rate Repo dengan Sesudah Kebijakan.

\section{REFERENSI}

Afriyanti, M. (2011). Analisis Pengaruh Current Ratio, Total Aset Turnover, Debt To Equity Ratio, sales, dan size terhadap ROA. Semarang.

Alamzah, N., \& Sanusi, A. (2015). Financial Decision, Innovation, Profitability and Company Value: Study on Manufacturing Company Listed in Indonesian Stock Exchange. 7(2), 72-78.

Barus, A. C., \& Leliani. (n.d.). Analisis Faktor-faktor yang mempengaruhi Profitabilitas pada perusahaan Manufaktur yang terdaftar di Bursa Efek Indonesia. Jurnal Wira Ekonomi Mikrosil, 3(2), 112.

Brigham, E. F., \& Houston, J. F. (2013). Dasar-dasar Manajemen Keuangan (11 Buku 2). Jakarta: Salemba Empat.

Indonesia, B. (n.d.). BI 7-day (Reverse) Repo Rate.

Iskandar, S. (2008). Bank dan Lembaga Keuangan Lain. Jakarta: Semesta Asa Bersama.

Kasmir. (2012). Analisis Laporan Keuangan. Jakarta: PT. RajaGravindo Persada.
Repo sebesar 16.59.

KJPP Tri, Santi \& Rekan. (2011). http://www.kjpptrisanti.com)

Missy, Yuanita, Budiyanto, \& Riyadi, S. (2016). Influence of capital structure, size and growth on profitability and corporate value. Ijbfmr, 4, 80-101.

Riyadi, S. (2016). Banking Asset and Liability Management. Jakarta: Fakultas Ekonomi $\&$ Bisnis.

Tailab, M. M. K. (2014). The Effect of Capital Structure on Profitability of Energy American Firms. 3(12), 54-61. https://doi.org/10.4018/978-1-46666635-1.ch018

\section{BIODATA PENULIS}

Sofyan Marwansyah, seorang staff akademik di universitas bina sarana informatika, mulai aktif mengajar pada tahun 2006 dan mulai aktif menulis jurnal pada tahun 2010 dengan jurnal pertama berjudul PENENTUAN PORTOFOLIO SAHAM YANG EFISIEN PADA LIMA PERUSAHAAN MINYAK DAN GAS BUMI (MIGAS) dijurnal perspektif.

Sri Rusiyati, seorang praktisi di bidang akunting, keuangan dan perpajakan yang mengabdikan diri sebagai dosen di Sekolah Tinggi Manajemen Informatika dan Komputer Nusa Mandiri Jakarta dan Universitas Bina Sarana Informatika Jakarta dan mulai aktif menulis jurnal pada tahun 2017 dengan judul pertama yaitu PENGARUH TINGKAT SUKU BUNGA SBI DAN KURS NILAI TUKAR RUPIAH TERHADAP DOLAR AS TERHADAP HARGA SAHAM PERUSAHAAN FARMASI DI BURSA EFEK JAKARTA di jurnal Cakrawala. 